\title{
Shaping Behaviour among Students in Zambia's Public Universities: Can Guidance and Counselling be Useful?
}

\author{
Abigail Tuchili ${ }^{1}$, Daniel Ndhlovu' ${ }^{2}$ \\ ${ }^{1}$ University of Zambia, School of Education, Lusaka. Zambia \\ ${ }^{2}$ University of Zambia, Institute of Distance Education, Lusaka. Zambia.
}

\begin{abstract}
How guidance and counselling services can shape students' behaviour in Zambia's public universities is not known. Thus the substantive aim of this study was to establish how guidance and counselling services can be used to shape students' behaviour. This paper is an excerpt from an on-going PhD thesis. A descriptive survey research design was used to collect, analyse and interpret both quantitative and qualitative data. A total of105 respondents who included Deans of Student's Affairs (DOSA), counsellors and students were selected for the study. In-depth interview guides, focus group discussions and self-administered questionnaires were used to collect data from the sample. The study established that guidance and counselling services can shape behaviour of students in Zambia's public universities. On the basis of the study findings, it is recommended that guidance and counselling be accessed by all students in public universities as it has the potential to shape and enhance positive behaviour among students.
\end{abstract}

Keywords: guidance and counselling; shape behaviour, character formation, deviate and demonstrations /riots.

\section{INTRODUCTION}

\section{Background to the Study}

A good and effective guidance and counselling programme is essential in every learning institution, just as an organised guidance and counselling programme will offer the right environment for the growth and development of the student and offer quality education UNESCO, (2000). Providing guidance refers to leading a person to self-actualisation or helping him or her to develop his or her full potential. Attaining self-actualisation may be difficult if a student is unaware of, or unrealistic about his or her potential. Bhatnagar \& Gupta (1999) define guidance as a process of helping the individual find solutions to his own problems and accept them as his own. They further say that guidance is an integral part of education. Guidance and Counselling services have been observed to help students to overcome social, psychological, cultural and educational problems that arise from their day to day life activities (Halim 1999). To this effect, some tertiary institutions in Zambia offer academic guidance and counselling as an aspect of students' support services. Despite guidance and counselling services being offered in schools in the last three decades, how these services can be used to shape student's behaviour in public universities is not known. Ndhlovu (2015), states that the role of guidance and counselling teachers in shaping students' behaviour is immensely needed in Zambian schools. He attributes the behavioural problems students face to lack of or in some cases improper counsel and indicates that these could be resolved through provision of guidance and counselling. A study that would examine how guidance and counselling services can be used to address deviant behaviour by students in tertiary institutions is therefore, necessary. According to Tuchili (2008), guidance and counselling services should include those services offered to students beside their formal lessons within the learning environment. These include personal, emotional, social, educational and vocational support services. These services form an important component in a student's wellbeing. However, it is common to see or read about riotous behaviour by students in public universities. As a result, several questions come to mind; are guidance and counselling services offered to students in public universities? If yes, how relevant to students are the guidance and counselling services provided in Zambia's universities? The constant demonstrations and riots at public universities made a former university student leader to advise the students to find better ways of resolving challenges they may encounter. The newspaper cutting below shows the advice given. 


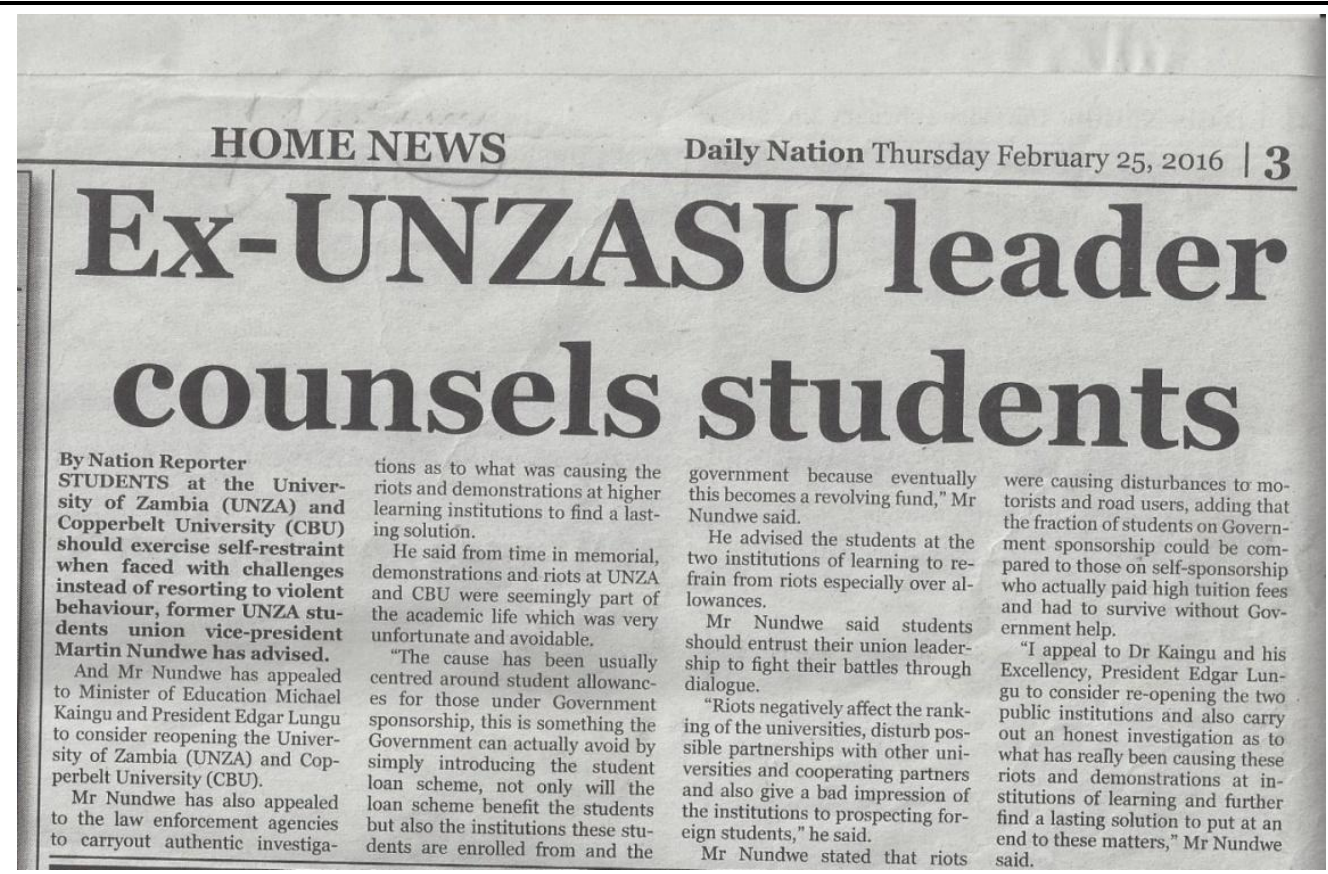

Hence, there was need to examine how guidance and counselling services can be used to shape behaviour of students in Zambia's public universities.

\section{Statement of the Problem}

Despite guidance and counselling services being offered in public universities in Zambia, there have been incidences of deviate behaviour among students and how the services can be used to shape behaviour is not known. The purpose of the study therefore, was to establish how guidance and counselling services can be used to shape students' behaviour in Zambia's public universities.

\section{OBJECTIVE}

To establish how guidance and counselling services can be used to shape students' behaviour.

\section{RESEARCH QUESTION}

How can guidance and counselling services be used to shape students' behaviour?

\section{SigNIFICANCE OF THE STUDY}

At the time when it is not known how guidance and counselling services can shape students' behaviour, a study of this nature is significant to fill this gap.

\section{STUDY SiTES}

The study sites for this study are: University of Zambia, Copper Belt University and Kwame Nkrumah University.

\section{METHODOLOGY}

The study used mixed methods of both qualitative and quantitative design. A descriptive survey research design was used to collect, analyse and interpret both quantitative and qualitative data. A total number of one hundred and five (105) respondents participated in the study. This number included: 90 students, 12 counsellor and 3 Deans of Student Affairs. The benchmark for inclusion of this sample was that these Deans are responsible for the students' affairs, while the counsellors are equally responsible for the students' needs by providing the guidance and counselling services to all students. The students had lived experiences of using the guidance and counselling services and would provide required data.

This study used purposive and simple random sampling procedures to select the sample. Purposive sampling technique was used to select participants from university officials while simple random sampling was used to select the students. Using questionnaires, quantitative data was collected from students and counsellors and analysed using the Statistical Package for Social Sciences (SPSS) to generate tables, graphs and percentages, while qualitative data was collected from Deans of Students Affairs (DOSA) and students through interviews and focus group discussions. It was decided to use these three sources of data so as to have a more holistic approach to the study of guidance and counselling services. These three sets of participants provided an opportunity for triangulating the 

Useful?

findings, an approach which increases credibility in the findings (Patton 1999; 2002). As such, the study findings from these three sources are presented concurrently.

\section{ETHICAL ISSUES}

Permission to conduct the study was obtained from the Ethical Committee of the University of Zambia and also from the Ministry of Higher Education in Zambia. Consent was also sought from all the three universities and participants. Confidentiality and anonymity was ensured at all stages of data collection. The purpose of the study was explained and respondents were given a chance to decide on whether to participate in the study and were assured that their names would remain anonymous.

\section{FINDINGS AND DISCUSSION}

Presented below are some of the areas of Guidance and Counselling Services (GCS) which have reportedly shaped students' behaviour in public universities in Zambia. The results indicate that students confirmed that access to GCS did shape their behaviour positively. The figure below indicates that $54.4 \%$ of students who accessed guidance and counselling services reported enhanced appropriate behaviour shaped toward academic achievement. However, $45.6 \%$ were not sure as to whether GCS had an effect on shaping their behaviour. From this finding, it is clear that guidance and counselling can shape behaviour of students in public universities in Zambia. This assertion is in line with an earlier finding by Nyaga (2011),'s study that revealed that GCS have an impact on students' wellbeing. This thus consequently shapes behaviour of students.

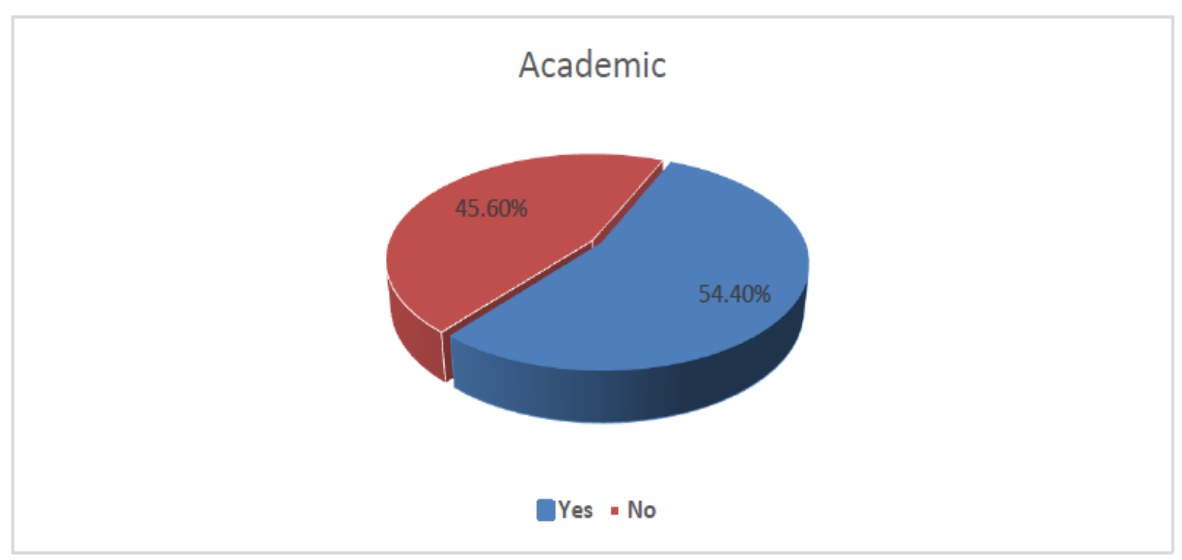

Figure1. Academic guidance helped to shape students behaviour towards academic work

\section{SOCIAL GUIDANCE}

Table 1 below shows that $74.4 \%$ of the students attributed their acceptable social behaviour to guidance and counselling they received at the university. Meanwhile, $25.6 \%$ were silent as to whether the source of positive behaviour was due to accessing guidance and counselling. This finding is line with Gatua et al (2015) whose study among students in Kenya's Rift Valley Province concluded that guidance and counselling services helps in modifying students' behaviour in social and emotional adjustments. Therefore, it may be safe to conclude that GCS can shape students behaviour in the public universities in Zambia. In the same vein, a counsellor had this to say: 'GCS encourages positive acceptable behaviour among students and helps to cognitively reconstruct their thinking'. Further, a student during the FGD agreed with this finding in the following words: 'It helps to shape the behaviour of us students not to get in trouble'; 'after being guided, you take the right decisions'. An interview extract from one DOSA sums it all in these words: 'definitely the behaviour is shaped ... you see the change in the way students behave...'

Table1. Students' Acceptable Behaviour Attributed to Social Guidance Received

\begin{tabular}{|l|l|r|r|r|r|}
\hline \multicolumn{7}{|c|}{ Social guidance } \\
\hline \multirow{3}{*}{ Valid } & yes & Frequency & Percent & Valid Percent & \multicolumn{2}{c|}{ Cumulative Percent } \\
\cline { 2 - 6 } & no & 67 & 74.4 & 74.4 & 100.4 \\
\cline { 2 - 6 } & Total & 23 & 25.6 & 25.6 & 100.0 \\
\hline
\end{tabular}




\section{DECISION MAKING SKILLS}

The results indicate that $75.60 \%$ attributed their improved positive behaviour in decision making skills to the guidance and counselling they received at the university while $24.40 \%$ were not certain. This finding is in agreement with reviewed literature by the following: Kangai et al (2011), who state that GCS helps in the students' wellbeing in regard to performance and choices the students make. Further this finding is similar to the study by Nweze and Okolie (2014) who found out that guidance and counselling play vital roles in assisting students through career decision-making. Other studies that are in agreement that GCS do help in regard to improving students' decision making skills are Sink and Stroh (2007), and Gysbers (2008). In the same regard, a study by Brigman and Campbell (2008); on career decision-making revealed a significant and positive relationship between GSC and students' behaviour in terms of achievement. It showed that effective guidance and counselling programme had a positive influence on students' career decision-making. This indicates that guidance and counselling is multifunctional and addresses many areas and needs of students. The findings imply that students could make right and informed career decisions once accorded the right environment. The findings of the study by Brigman and Campbell (2008) used a quasi-experimental, pre-post-test design to evaluate the impact of a school-counselling-led intervention on student academic achievement and school success behaviours. The study reported that impact of a schoolcounselling-led intervention on student academic achievement and school success behaviours helped them to be better in their social and academic life.

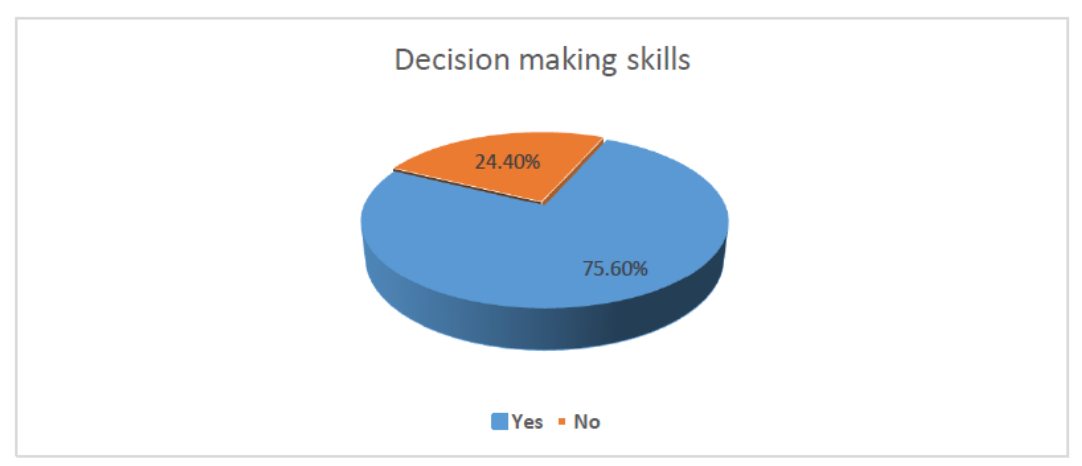

Figure2. Decision-Making Skills among Students on Shaping Behaviour

The results above are further confirmed by the information from the FGDs in which the students responded as follows: 'We receive guidance under decision-making skills, social and academic skills and these help shape one's behaviour'. 'It helps to shape the behaviour of us students not to get in trouble'. 'After being guided we take the right decisions'. These findings are line with K'okul (2010), Nyaga (2011) and Mikaye (2012); whose studies revealed that guidance and counselling does shape behaviour of students who access the service.

\section{Relevance on How Guidance and Counselling Can Shape Students' Behaviour}

In the study it was important to find out to how Guidance and Counselling Services can shape students' behaviour. This was necessary because the focus of the objective of the study was to establish how guidance and counselling could be used to shape students' behaviour. The answers are as outlined: 'Even when one is in trouble we receive guidance especially from the lecturers in the Special Education Department and DOSA,'said some students. Others further stated that: 'the services are relevant because they help us students to change to acceptable behaviour.' 'Some students indicated that 'all students received guidance during orientation and this makes it easier to seek help when in trouble.' 'Guidance and counselling helps especially when making decisions of academic or social nature'. Other students said: 'Conduct of students changes when one receives guidance. Yes, behaviour is shaped positively, meaning acceptable and appropriate behaviour'. 'As regard to general misbehaviour, when a student is counselled they change to acceptable behaviour as they are reminded on consequences and to concentrate on school'. The students stated categorically that guidance and counselling helps to shape the behaviour of students to acceptable behaviour. The researcher is of the opinion that guidance and counselling does indeed shape behaviour of students who access the service.

On the same question of whether guidance indeed does shape students' behaviour, the counsellors who responded to the questionnaire indicated as below: 

Useful?

\section{Counsellor Responses on Whether GCS Can Shape Students' Behaviour}

The table below indicates that nine (9) of the 12 counsellors who responded to the questionnaire said guidance and counselling services shaped students' behaviour while three (3) were not so sure as to whether they would attribute behaviour change to the provision of GCS. This finding is confirmed by Nyaga (2011), Mikaye (2012); and Gatua et al (2015) who argued that GCS can help shape behaviour of students. The study by Nyaga found that GCS had a positive impact on emotional, social and academic achievements for students. While that by Gatua and Mikaye, equally revealed that students' wellbeing improved as they accessed GCS. Based on these findings, the researchers are of the view that guidance and counselling shaped students' behaviour.

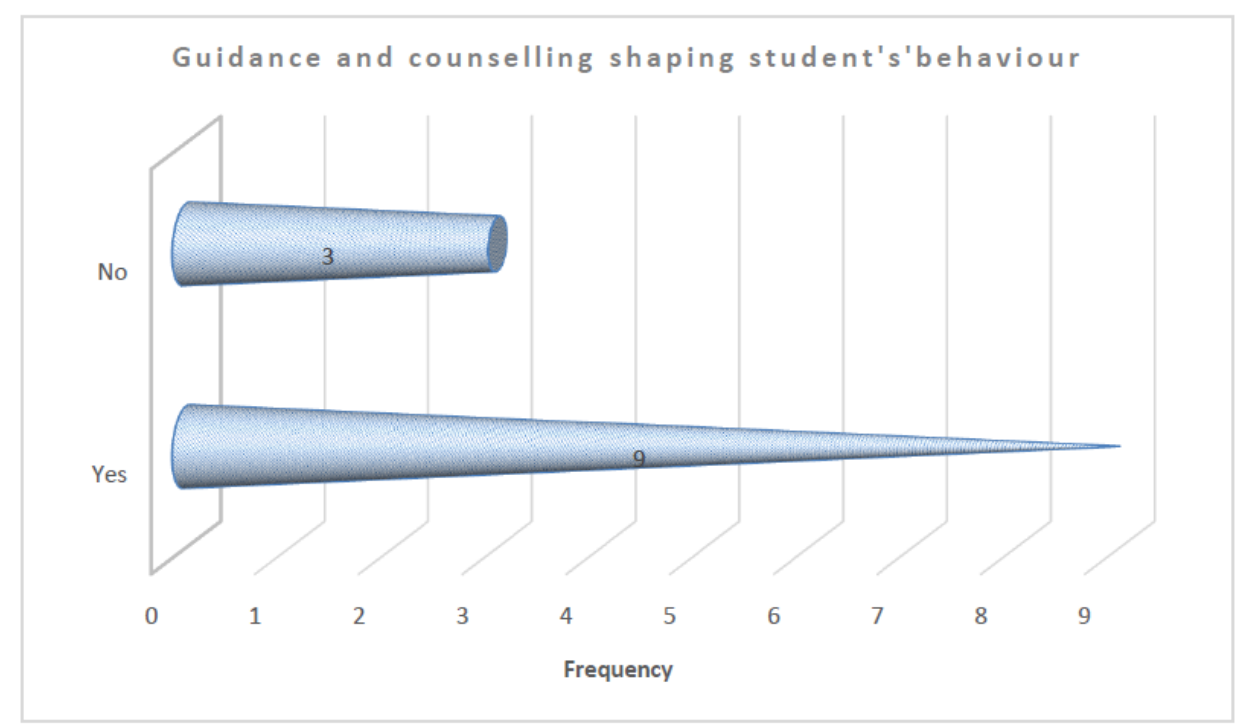

Figure3. Counsellor Responses on Guidance and Counselling Shaping Students' Behaviour

The Deans indicated in the responses during the interviews that:

'After receiving counselling, some students have confessed to have become more positive about life, confident and record improved results'. GCS are very relevant in shaping students' behaviour. Those that receive counselling attest to this'. 'It harmonises students' as each is expected to accommodate the other as they fully get to understand and accept each other'. This finding is in agreement with K'okul (2010) and Nyaga (2011). Some deans had this to say: 'Counsellors help instil positive appropriate behaviour and management of stress among students using GCS'. 'When some students get into the university, they are not sure what they want to do so GCS helps to resolve shape the behaviour to make choices in a particular manner'. Further another dean said: 'GCS encourages positive acceptable behaviour among students.' 'Personal behaviour of students is improved; 'Personal growth is improved in different aspects of a student's life'. 'It helps students come to terms with a situation they may find themselves in so for sure it helps shape behaviour in a particular direction'. Additionally, another dean stated: 'It helps to shape them. The answer is definitely 'yes', counselling is psychological treatment just like physical treatment just like malaria treatment, counselling changes students behaviour. Those who seek the service change. 'Definitely the behaviour is shaped ... you see the change in the way students behave...' response is equally based on annual reports which shows number of students who have used various services and ultimately behaviour gets shaped through services they receive.'

Further asked if behaviour is shaped after guidance and counselling: the Dean of Students Affairs (DOSA) answered in the affirmative ...definitely yes'....The DOSAs further added: 'guidance and counselling would help shape students in making informed decisions about both academic and personal life.' Students who receive guidance and counselling, even as group guidance try hard to avoid getting into trouble and remaining focused.' Consequently, their behaviour is shaped positively because of accessing GSC.' The above findings are in agreement with Mikaye (2012); and Gatua et al (2015) who reveal that behaviour of students is modified and shaped positively if the students access guidance and counselling. The discussions and responses do seem to suggest that guidance and counselling services can shape behaviour of students in public universities in Zambia. The researchers 
thus agree with the findings. However, the researchers are of the view that what is even more critical is the provision and access of quality services to students.

As such career counselling should be given equal attention as academic performance and counselling on social and behavioural issues. The DOSAs corroborated these responses by stating that: 'There has been remarkable improvement in students' behaviour and decision making due to counselling. The students have also started changing subjects of their choices to suit their passion and academic capabilities'. This implies that, guidance and counselling played a vital role of informing the students on the best way to behave and also to choose courses based on passion and academic capabilities. This is likely to result to students making the right career decisions. These findings are similar to those revealed by a study carried out by Odongo and Njiru (2010) who found out that effective counselling enabled students to be more productive and approach their academic work with confidence. The implication of this finding is that, counselling services should be effective and reach all students especially not on career issues but all aspects of GCS.

\section{CONCLUSION AND RECOMMENDATIONS}

\section{CONCLUSION}

This study attempted to answer the question on how guidance and counselling can be used to shape students' behaviour in public universities in Zambia. Based on the data gathered, the study has established that guidance and counselling can shape students' behaviour in Zambia's public universities. The conclusion is premised on responses from students, counsellors and DOSAs who all acknowledge that guidance and counselling can be used to enhance positive behaviour in students and consequently shape the behaviour positively. It may also be concluded that if students are guided on how to handle the social and academic challenges they encounter through the choices they make and also the demands of everyday life they would make informed decisions about their prosperity.

\section{RECOMMENDATIONS}

Based on the perceived benefits of guidance and counselling as a tool of shaping students' behaviour, it is recommended that:

- Guidance and Counselling be accessed by all students in public universities as it has the potential to shape and enhance positive behaviour among students.

- Increase number of counsellors in all public universities. This is because the number of students is too large to be attended to by the few counsellors in the universities.

\section{REFERENCES}

Bhatnagar, A. \& Gupta N. (1999).Guidance and Counseling. Vol. II, New Delhi: National Council of Education.

Cresswell, J. W., \& V. L. Plano Clark. (2007). Designing and Conducting Mixed Methods Research. Thousand Oaks, CA: Sage Publications.

Daily Nation Newspaper. (2016). 25th February, 2016. Lusaka: Daily Nation.

Gay, L.R. and Diehl, P.L. (1992).Research Methods for Business and Management. In Hill, R.(1998). "What Sample Size is 'Enough' in Internet Survey Research'? Interpersonal Computing and Technology: An electronic Journal for the $21^{\text {st }}$ Century. Available at: http:// www. emoderators. com/ipct-j/1998/n3-4/hill.hmtl

Gatua, D. M. et al (2015). Impact of Guidance and Counselling Services on Students' Behaviour Modification between Selected Public Urban and Rural Secondary Schools in Rift Valley Province, Kenya. Research on Humanities and Social Sciences ISSN (Paper)2224-5766 ISSN (Online)2225-0484 (Online) Vol.5, No.19, 2015.

Gibson, R. L. and Mitchell, M. H. (2007).Introduction to Guidance and Counselling. $7^{\text {th }}$ ed. New York: Macmillan

Ibrahim, R. et. Al (2014).Perceptions on the Role of Guidance and Counselling Programme on Kenyan Secondary School Students' Career Decision Making. Journal of Educational and Social Research. MCSER Publishing, Rome-Italy Vol. 4 No.6

Kombo, K. D. and Tromp, L. A. (2006).Proposal and Thesis Writing: An Introduction Nairobi: Pauline Publications Africa. 
Shaping Behaviour among Students in Zambia's Public Universities: Can Guidance and Counselling be Useful?

K'okul Florence S. A. (2010) Perceptions of Students on the Status Of Guidance and Counselling In Selected Universities In Kenya For Minimizing Student Riots Unpublished PhD Thesis, Kenyatta University: Nairobi.

Mikaye, D. O. (2012)Influence Of Guidance And Counselling On Students' Discipline In Public Secondary Schools in Kabondo Division, Kenya. Unpublished MA Thesis: Nairobi University

Ministry of Education (1996).Educating Our Future: National Policy on Education, Lusaka: ZEPH.

Mutie, E. K. \&Ndambuki, P. (2004). Guidance and Counselling for Schools and Colleges. Nairobi: Oxford University Press.

Ndhlovu, D. (2015). Theory and Practice of Guidance and Counselling for Schools and Colleges. Lusaka: University of Zambia Press.

Nyaga, K. V. (2011). Effectiveness of Guidance and Counselling Services and Development of Students' Academic, Social and Personal Competencies in Public and Private Universities in Kenya: Doctoral Dissertation, MeruChuka University College.

Nweze, T. And Okolie U.C. (2014). Effective Guidance and Counselling Programmes in Secondary Schools: Issues and Roles in Students' Career Decision Making. IOSR Journal of Research \& Method in Education (IOSR-JRME) e-ISSN: 2320-7388,p-ISSN: 2320-737X Volume 4, Issue 4 Ver. V

Patton, M. Q. (2002). Qualitative evaluation and research methods (3rd ed.). Thousand Oaks, CA: Sage Publications, Inc.

UNESCO (2000) Module 8.Guidance and Counselling Programme Development. Botswana.30 Volume 11, No. 1, June 2011 The African Symposium (ISSN\# TX 6-342-323)

UNESCO (2000).Guidance Module 1. Paris: Ag2i Communication.

Odongo, M. \&Njiru, L. (2010).Motivating the Girl child through Counseling. Kisumu: JKF

Tuchili, A. M. (2008). Evaluation of school guidance and counselling services provision in Selected schools in Lusaka District. Unpublished MA. Thesis. UNZA: Lusaka.

\section{AUTHORS' BIOGRAPHY}

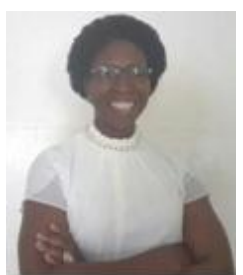

Abigail Tuchili, is an Educational Psychologist and a $\mathrm{PhD}$ candidate in the School of Education, Department of Educational Psychology, Sociology and Special Education (EPSSE) at the University of Zambia. She is currently serving as Senior Curriculum Specialist at the Curriculum Development Centre (CDC) in the Ministry of General Education (MOGE) - Zambia. She has over 10 years' experience in the field of curriculum design and development and over 13 years' as a teacher. Her PhD thesis is about 'How guidance and counselling can shape students' behaviour in selected public universities in Zambia'. Abigail has participated in various National and International fora on guidance and counselling. She is currently a member of the Psychology Association of Zambia (PAZ) and National Counselling and Guidance Association of Zambia (NACGAZ); and part time lecturer of Educational Psychology at the University of Lusaka.

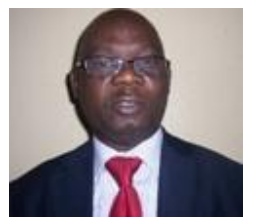

Dr. Daniel Ndhlovu, is a Senior lecturer in the Department of Educational Psychology, Sociology and Special Education at the University of Zambia. He holds a doctoral degree in Special Education, Master's degree in Education and Bachelor's degree in Special Education from the University of Zambia. In addition to lecturing, he has held senior administrative positions at the University of Zambia which includes Assistant Dean Postgraduate in the School of Education and Assistant Director Postgraduate in the Institute of Distance Education. He has over 29 years teaching and lecturing experience at secondary school and tertiary levels of education. Dr. Ndhlovu is also the current president of the National Counselling and Guidance Association of Zambia (NACGAZ). He has done numerous research activities and publications in local and international refereed journals. His latest publication is of 2016 and titled Effects of Guidance and Counselling Services on Students' Interpersonal, Study, Vocational and Problem-Solving Skills in Selected Public Universities in Zambia." Authored by Tuchili, M. A. and Daniel Ndhlovu. International Journal of Humanities Social Sciences and Education (IJHSSE), ISSN: 2349-0373, Vol. 3, Number 12, December, Pp14-20 